\title{
Job satisfaction and its relationship with organisational commitment: A Democratic Republic of Congo organisational perspective
}

\begin{tabular}{|c|c|}
\hline \multicolumn{2}{|c|}{$\begin{array}{l}\text { Authors: } \\
\text { Jeremy Mitonga-Monga }{ }^{1} \\
\text { Aden-Paul Flotman }^{2} \text { (D) } \\
\text { Frans Cilliers }^{2} \text { (D) }\end{array}$} \\
\hline \multicolumn{2}{|c|}{$\begin{array}{l}\text { Affiliations: } \\
{ }^{1} \text { College of Economic and } \\
\text { Management Sciences, } \\
\text { University of South Africa, } \\
\text { South Africa }\end{array}$} \\
\hline \multicolumn{2}{|c|}{$\begin{array}{l}{ }^{2} \text { Department of Industrial } \\
\text { and Organisational } \\
\text { Psychology, School of } \\
\text { Management Sciences, } \\
\text { University of South Africa, } \\
\text { South Africa }\end{array}$} \\
\hline \multicolumn{2}{|c|}{$\begin{array}{l}\text { Corresponding author: } \\
\text { Aden Flotman, } \\
\text { flotma@unisa.ac.za }\end{array}$} \\
\hline \multicolumn{2}{|c|}{$\begin{array}{l}\text { Dates: } \\
\text { Received: } 30 \text { Nov. } 2017 \\
\text { Accepted: } 14 \text { Feb. } 2018 \\
\text { Published: } 21 \text { June } 2018\end{array}$} \\
\hline \multicolumn{2}{|c|}{$\begin{array}{l}\text { How to cite this article: } \\
\text { Mitonga-Monga J., } \\
\text { Flotman, A-P. \& Cilliers, F., } \\
2018 \text {, 'Job satisfaction and } \\
\text { its relationship with } \\
\text { organisational commitment: } \\
\text { A Democratic Republic of } \\
\text { Congo organisational } \\
\text { perspective', Acta Commercii } \\
\text { 18(1), a578. https://doi. } \\
\text { org/10.4102/ac.v18i1.578 }\end{array}$} \\
\hline \multicolumn{2}{|c|}{$\begin{array}{l}\text { Copyright: } \\
\text { (C) 2018. The Authors. } \\
\text { Licensee: AOSIS. This work } \\
\text { is licensed under the } \\
\text { Creative Commons } \\
\text { Attribution License. }\end{array}$} \\
\hline \multicolumn{2}{|l|}{ Read online: } \\
\hline 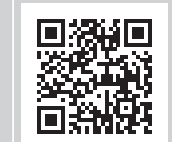 & $\begin{array}{l}\text { Scan this QR } \\
\text { code with your } \\
\text { smart phone or } \\
\text { mobile device } \\
\text { to read online. }\end{array}$ \\
\hline
\end{tabular}

Orientation: The modern workplace, which is characterised by increasing turbulence and debilitating uncertainty, has led to renewed focus on whether employees experience satisfaction and how they commit themselves to the organisation.

Research purpose: The aim of this study was to measure the nature of the relationship between employees' levels of job satisfaction (JS) and organisational commitment (OC) in a public railway organisation in the Democratic Republic of Congo (DRC).

Motivation for the study: Although previous researchers have found evidence of the relationship between JS and OC in Western countries, there seems to be a paucity of research on the relationship between JS and OC in a developing country context such as that of the DRC. The results could make a valuable contribution to the current literature debate on these two constructs (JS and OC) and possibly employees' intention to stay in their present organisation.

Research design, approach and method: A cross-sectional survey design was used employing the Job Satisfaction Questionnaire and the Organisational Commitment Scale. The sample $(n=839)$ comprised permanently employed staff. Correlations and regression analyses were conducted. The results indicated that employees' JS related positively to their level of OC and that JS predicted OC.

Practical and managerial implications: The results should also have interesting implications for top management and human resource practitioners. They could use this information to study how organisational psychological attachment is fostered in order to potentially master other organisational dynamics. The information could also be used to create positive working conditions with a view to reinforcing OC. JS manifested as a critical driver of OC, which could result in superior business performance. Management could use the results to create a working environment that actively fosters satisfaction and boosts employees' level of commitment.

Contribution or value-add: The results should contribute to the body of knowledge on the relationship between JS and OC in the context of a developing economy and highlight the practical implications for line managers and behavioural and wellness practitioners.

\section{Introduction}

As organisations are considered to be a major pillar of the effective economic development of a country, which produces goods and services, the attraction and retention of employees in those organisations remain a critical issue for researchers and scholars (Sehunoe, Viviers \& Mayer 2015:124). Organisations functioning in a global turbulent business environment are struggling to render high-quality services and customer satisfaction with fewer resources (Spagnoli \& Caetano 2012:257). Employees' job satisfaction (JS) and organisational commitment (OC) are of particular importance to the survival and profitability of these organisations (Coetzee \& Schreuder 2015:119-120). The focus of this research was investigation of the relationship between JS and OC, as these two constructs are assumed to directly affect organisational effectiveness and efficiency. JS behaviours refer to employees' emotional orientation towards their work (Huang, You \& Tsai 2012:520; Locke 1976:301), while OC is perceived as the strength of individuals' identification with and involvement in a particular organisation (Chiu \& Ng 2013:85-86; Obi-Nwosu, Chiamaka \& Tochukwu 2013:485). Satisfied employees tend to be motivated, perform well in their day-today work and demonstrate a deep psychological bond with the organisation (Stander \& Rothmann 2010:3-4). Previous research has established that JS predicts employees' OC, performance, low turnover rate and turnover intention, as well as low absenteeism, and positively 
affects organisational efficiency and effectiveness (Ayeni \& Phopoola 2007:155-156; Chiu \& Ng 2013:90-91; Judeh 2011:178; Kotze \& Roodt 2005:51; Lumley et al. 2011:111). Although previous researchers have found evidence of the relationship between JS and OC in Western and international countries (Aamodt 2007:121; Carmeli \& Freund 2004:295296; Rutherford et al. 2009:1148), there seems to be a paucity of research on the relationship between JS and OC in a developing country context such as that of the Democratic Republic of Congo (DRC).

\section{The research context}

Despite recent progress on the economic front, with sustained growth of approximately $8.9 \%$ (Mokime \& Bamou 2015), the DRC in general and the transport industry in particular are still characterised by poor infrastructure, serious socioeconomic inequalities, inadequate educational and health services and few job opportunities, particularly for young people (Kanyurhi 2016:361; Mminele 2014). However, growth is expected to be strong during 2016/2017, in both the public and private sectors, and infrastructure building programmes should result in better links between regions and provinces (Mokime \& Bamou 2015). The interaction of the above-mentioned adverse conditions would pose potential risks for organisations in terms of the well-being, psychological impact and morale of employees. It would therefore be to the advantage of organisations to harness the expected growth and positive economic momentum. The insights gained from the present empirical study on the relationship between JS and OC could result in the development of effective engagement strategies and the nurturing of psychological well-being among employees - not only in the transport industry but also in organisations in general in this developing economy.

\section{Theoretical perspectives Job satisfaction}

The large volume of research conducted on JS reflects the complexity of this construct (Lee \& Cha 2015:361; Lumley et al. 2011:111). JS has been defined as a positive and favourable attitude (Armstrong 2006:33-34) or pleasurable emotional state resulting from an assessment of one's job experience (Locke 1976:302; Zhang \& Zheng 2009:335). High JS is associated with positive attitudes, while low JS reflects dissatisfaction and a negative attitude towards one's job (Evans, Pucik \& Bjorkman 2011:87-88; Schmidt 2007:489; Robbins 1993:121). If one assumes that all employees function according to a set of values, a belief system, assumptions and expectations, JS is seen as the extent to which employees perceive that these are being met through their personal working experience. It is therefore apparent that there is a strong subjective element in JS because it reflects the intrinsic and extrinsic needs, likes and dislikes of employees (Robertson \& Cooper 2011:125).

For the purpose of this study, the five facets of JS identified by Smith, Kendell and Hulin (1969:88), which are regarded as the most popular dimensions of JS (Swaminathan \& Jawahar 2013:74-75), were used. These are satisfaction with pay [when an employee experiences congruence between compensation and the amount of effort he or she invests (Ebert \& Griffin 2009:125)], satisfaction with promotion [when perceived expectations match actual expectations, resulting in a perception of promotion fairness (Evans et al. 2011:89)], satisfaction with supervisors [when supervisory practices are experienced as competent, fair and trusting (Özturk 2010)], satisfaction with co-workers [when colleagues enjoy positive working relations and practise an honest work ethic (Ebert \& Griffin 2009:126)] and satisfaction with the work itself [when there are positive perceptions about working conditions, working hours and clear role and task expectations (Evans et al. 2011:190)]. Employees with positive working experiences in the above dimensions of JS are therefore likely to remain in the organisation and demonstrate high levels of loyalty and commitment to it (Faragher, Cass \& Cooper 2005:106; Aziri 2008:78). Satisfied employees tend to be committed to the organisation, excel at work and display behaviours that support organisational goals and objectives (Aamodt 2007:123; Lumley et al. 2011:108). Ng and Wyrick (2011:369) found that satisfied employees are likely to evoke feelings of attachment and loyalty, which have a positive effect on employees' intention to stay, organisational performance, efficiency and effectiveness.

\section{Organisational commitment}

A number of definitions have been formulated to explain the concept of OC. A common view is that OC contains a 'psychological bond' (Allen \& Meyer 1990:10-11; Humphreys, Weyant \& Sprague 2003:201) that explains employee workplace behaviour. According to Fu and Deshpande (2013:6), OC is a measure of employees' attachment to and identification with their job. This involves a work attitude related to employees' willingness to be actively involved in the work (and life) of the organisation and to subsequently stay employed in the organisation (Lok \& Crawford 2004:322). Such employees would be willing to expend their efforts in and demonstrate loyalty to the organisation (Lee \& Cha 2015:360; Rashid, Sambasivan \& Johari 2003:717; Yiing \& Ahmad 2009:70) and develop a predisposition and emotional attachment that is psychologically aligned with the organisation's strategic intent (Beer 2009:128; Narteh 2012:410). All these behaviours are a result of the normative pressures experienced by employees (Allen \& Meyer 1990:12; Viljoen \& Rothmann 2009:710). Following Reichers's (1985:469) notion, Mamman, Kamoche and Bakuwa (2012:289) supported the categorisation of this collection of commitments into what they refer to as global and local commitments, characterised by varying unique and specific outcomes. Employee OC is therefore a strong identification with and psychological attachment to the organisation, which inspires them to actively participate in the accomplishment of organisational aims and objectives (Meyer \& Allen 1997:125-127).

Meyer and Allen's (1991:70-71) three-component model of OC, as the dominant framework in the literature, was used in 
this study, namely affective, continuance and normative commitment. Affective commitment (emotional attachment) refers to employees' psychological bond to the organisation because they want to stay (Meyer \& Allen 1991:71). Continuance commitment (economic necessity) denotes the perceived costs associated with leaving the organisation. The employee is attached to the organisation out of economic obligation, because of the need to do so (Allen \& Meyer 1990:12). Normative commitment (moral obligation) refers to the perceived obligation to remain in the organisation because it is the correct and moral thing to do (Allen \& Meyer 1990:12).

\section{Integration}

Previous research on JS and OC reveals a strong positive relationship between the two constructs (Brown \& Peterson 1993:65-66; Hunt, Chonko \& Wood 1985:114-115; Kotze \& Roodt 2005:50). Conversely, Curry et al. (1986:851) reported no significant relationship between the constructs. However, the literature strongly supports the notion that satisfaction results in commitment (Huang et al. 2012:515; Mueller et al. 1994:182). Meyer et al. (2002:23) found a positive relationship between JS and affective commitment, while Fu, Deshpande and Zhao (2011:539) supported this finding by reporting that certain dimensions of JS (pay, co-worker supervision and the work itself) had a significant impact on OC.

Researchers have also argued in favour of a causal association between OC and outcomes such as JS and organisational citizenship behaviour (Cohen 2007:57; Mamman et al. 2011:286; Ng \& Wyrick 2011:370). Employees thus tend to display commitment when they enjoy satisfactory working relationships (Asiedu, Sarfo \& Adjei 2014:289; Mathieu \& Zajac 1990:175). The general notion reflects the fact that OC is likely to evoke feelings of attachment and affiliation, which has a positive effect on organisational performance, efficiency and effectiveness. In light of the relationship between JS and OC, it is hypothesised that JS would relate positively and significantly to OC.

\section{Aim of the study}

The aim of this study was to measure the nature of the relationship between employees' levels of JS and organisational commitment in a public railway organisation in the DRC. The following research question guided the investigation: 'How does employees' perceived job satisfaction relate to their level of organisational commitment in the DRC?' The researchers envisioned that the results would make a valuable contribution to the current literature debate on these two constructs (JS and OC) and possibly employees' intention to stay in their present organisation.

\section{Method \\ Design and participants}

The research design was non-experimental and a crosssectional survey design was used (Cohen, Manion \& Morrison 2013; Shaugnessy \& Zechmeister 2003:147-148).
A non-experimental design encompasses a range of distinct methods, which aim to describe the association between constructs without testing any causal relationships between them (Tredoux \& Durrheim 2013:193). Convenience sampling (Salkind 2014:332; Tredoux \& Durrheim 2013:201) $(N=2500)$ consisting of a readily available and accessible population of permanently employed staff in a public rail transport organisation in the DRC was used. Out of 2500, only 839 were found to be usable and this yielded a response rate of $33.56 \%$. The sample consisted of $32 \%$ females, in early to middle adulthood (26-40 years). Of these, $46 \%$ were married, $32 \%$ had university education and most had between 6 and 10 years' work experience in the organisation.

\section{Measures}

The Job Satisfaction Questionnaire (JSQ) (Vitell \& Davis 1990:490) and the Organisational Commitment Scale (OCS) (Meyer \& Allen 1997:212) were used as measuring instruments for this study. The French versions of both instruments were used, as French is the official language in the DRC.

The JSQ is a 20-item self-reporting measure of employees' JS relating to the dimensions of pay, promotion, co-workers, supervisor and the work itself. The JSQ uses a five-point Likert scale ( 1 = strongly disagree; $5=$ strongly agree). Vitell and Davis (1990:492) reported on the questionnaire's internal consistency reliability coefficient $(0.76-0.89)$. The present study obtained an internal consistency coefficient ranging from 0.72 to 0.92 . The OCS is a 24 -item self-reporting measure of employees' OC relating to the dimensions of affective, continuance and normative commitment. The OCS uses a five-point Likert scale ( 1 = strongly disagree; 5 = strongly agree). Meyer and Allen (1997:187) reported on the scale's internal consistency reliability coefficient (0.83-0.90). The present study obtained an internal consistency coefficient ranging from 0.83 to 0.88 . Nunnally and Bernstein (2010:198) suggested a desirable cut-off point for Cronbach's alpha coefficients of 0.70-0.80, while Cohen et al. (2013:88) suggested $0.60-0.80$. Hence the present study's reliability data for both instruments was interpreted as acceptable for interpretation.

\section{Statistical analysis}

The SPSS program (SPSS 2017; version 24) was used to analyse the data, yielding means, standard deviations, internal consistency reliabilities, correlations and stepwise multiple regressions. Correlation analysis was used to examine the relationship between JS and OC. It was decided to set the statistical significance cut-off value at the $95 \%$ confidence interval level $(p \leq 0.005)$ (Tabachnick \& Fidell 2010:157-160). Stepwise multiple regressions were used to determine whether or not JS (as the independent variable) acts as a predictor of employees' OC (as the dependent variable). A $R^{2}$ value larger than 0.13 (medium effect) at $p \leq 0.05$ was regarded as practically significant (Cohen 1992:155-156). 


\section{Ethical considerations}

Permission to conduct this study was obtained from the organisation's management as well as the University of South Africa's Research Ethics Review Committee (No.11/40AO22/SD-Form/2013). The sample received a sealed envelope that included the following: an invitation letter, management's approval to conduct the study, a participant informed consent form soliciting the individual's consent and voluntary participation in the research project, a biographical questionnaire (requesting the participant's gender, age, marital status, education and tenure in the organisation) as well as the JSQ and the OCS. They were asked to sign the consent form, complete the JSQ and OCS and return these to the researcher.

\section{Empirical results}

Table 1 presents the descriptive statistics relating to the two variables being investigated, namely JS and OC (means, standard deviations, correlations indicating the internal consistency Cronbach's alphas). In terms of the JSQ (JS) variables, satisfaction with co-workers obtained the highest mean score $($ Mean $[\mathrm{M}]=4.15$; standard deviation $[\mathrm{SD}]=0.55)$, followed by total job satisfaction $(\mathrm{M}=4.03$; $\mathrm{SD}=0.52)$, satisfaction with the work itself $(\mathrm{M}=4.02$; $\mathrm{SD}=0.62)$, satisfaction with promotion $(\mathrm{M}=4.01 ; \mathrm{SD}=0.61)$, satisfaction with supervisor $(\mathrm{M}=4.00$; $\mathrm{SD}=0.74)$ and satisfaction with pay $(\mathrm{M}=3.95 ; \mathrm{SD}=0.73)$. In terms of the OCS (organisational commitment) variables, the sample scored highest on normative commitment $(\mathrm{M}=4.13$; $\mathrm{SD}=0.59)$, followed by total organisational commitment $(\mathrm{M}=4.09 ; \mathrm{SD}=0.54)$, continuance commitment $(\mathrm{M}=4.08 ; \mathrm{SD}=0.55)$ and affective commitment $(\mathrm{M}=4.07 ; \mathrm{SD}=0.55)$. All three components indicated a relatively high level of OC in the sample.

Table 1 also presents the significant correlation coefficients identified between the JSQ and OCS variables. The intercorrelations ranged from $r \geq 0.41$ (medium practical effect size) to $r \geq 0.87$ (large practical effect size). These results indicated that the zero-order correlations were below the threshold level of concern $(r \geq 0.90)$ of multicollinearity. Total, affective, continuance and normative commitment were positively and significantly related to the JSQ variables of satisfaction with pay, satisfaction with promotion, satisfaction with co-workers, satisfaction with supervisor and satisfaction with the work itself (the $p$-values ranged between $p \leq 0.001$ and $p \leq 0.05)$.

\section{Standard multiple regression}

Table 2 indicates the regression results.

The JS variables of satisfaction with pay, satisfaction with promotion, satisfaction with co-workers and satisfaction with the work itself showed a significant regression model $\left(F_{(7,826)}=258.77\right)$, accounting for $61 \%\left(R^{2}=0.61 ; p \leq 0.001\right.$; large practical effect) of variance in affective commitment. More specifically, satisfaction with supervisor $(\beta=0.34$; $t=11,12$; $p \leq 0.001)$, satisfaction with pay $(\beta=0.27 ; t=8.97 ; p \leq 0.001)$, satisfaction with the work itself $(\beta=0.13 ; t=4.13 ; p \leq 0.001)$, satisfaction with promotion $(\beta=0.12 ; t=4.21 ; p \leq 0.001)$ and satisfaction with co-workers $(\beta=0.10 ; t=3.88$; $p \leq 0.001)$ contributed significantly towards explaining the proportion of variance in the OCS affective commitment variables.

The JS variables of satisfaction with pay, satisfaction with promotion, satisfaction with co-workers and satisfaction with the work itself produced a statistically significant regression model $\left(F_{(7,826)}=181.11\right)$, accounting for $52 \%\left(R^{2}=0.52 ; p \leq 0.001\right.$; large practical effect) of variance in continuance commitment. More specifically, satisfaction with pay $(\beta=0.30 ; t=8.90 ; p \leq$ $0.001)$, satisfaction with the work itself $(\beta=0.20 ; t=4.38$; $p \leq$ $0.001)$, satisfaction with promotion $(\beta=0.09 ; t=2.84 ; p \leq 0.001)$ and satisfaction with supervisor $(\beta=0.05 ; t=6.61 ; p \leq 0.001)$ contributed significantly towards explaining the proportion of variance in the OCS continuance commitment variable.

The JS variables of satisfaction with pay, satisfaction with promotion, satisfaction with co-workers, satisfaction with

TABLE 1: Means, standard deviations and correlations.

\begin{tabular}{|c|c|c|c|c|c|c|c|c|c|c|c|c|}
\hline Variables & Mean & SD & 1 & 2 & 3 & 4 & 5 & 6 & 7 & 8 & 9 & 10 \\
\hline $\begin{array}{l}\text { Total } \\
\text { Job satisfaction }\end{array}$ & 4.03 & 0.52 & $(0.92)$ & - & - & - & - & - & - & - & - & - \\
\hline Satisfaction with pay & 3.95 & 0.73 & $0.81 * *$ & $(0.86)$ & - & - & - & - & - & - & - & - \\
\hline $\begin{array}{l}\text { Satisfaction with } \\
\text { promotion }\end{array}$ & 4.01 & 0.61 & $0.77 * *$ & $0.57 * *$ & $(0.74)$ & - & - & - & - & - & - & - \\
\hline $\begin{array}{l}\text { Satisfaction with } \\
\text { co-workers }\end{array}$ & 4.15 & 0.55 & $0.69 * *$ & $0.41 *$ & $0.44 *$ & $(0.72)$ & - & - & - & - & - & - \\
\hline $\begin{array}{l}\text { Satisfaction with } \\
\text { supervisor }\end{array}$ & 4.00 & 0.74 & $0.83 * *$ & $0.61 * *$ & $0.52 * *$ & $0.45^{*}$ & $(0.84)$ & - & - & - & - & - \\
\hline $\begin{array}{l}\text { Satisfaction with the } \\
\text { work itself }\end{array}$ & 4.02 & 0.67 & $0.81 * *$ & $0.55 * *$ & $0.53 * *$ & $0.52 * *$ & $0.61 * *$ & $(0.80)$ & - & - & - & - \\
\hline $\begin{array}{l}\text { Total Organisational } \\
\text { commitment }\end{array}$ & 4.09 & 0.54 & $0.77 * *$ & $0.66 * *$ & $0.57 * *$ & $0.49 *$ & $0.70 * *$ & $0.60 * *$ & $(0.94)$ & - & - & - \\
\hline Affective commitment & 4.07 & 0.55 & $0.72 * *$ & $0.63 * *$ & $0.52 * *$ & $0.43^{*}$ & $0.62 * *$ & $0.60 * *$ & $0.85 * *$ & $(0.86)$ & - & - \\
\hline $\begin{array}{l}\text { Continuance } \\
\text { commitment }\end{array}$ & 4.08 & 0.65 & $0.70 * *$ & $0.56 * *$ & $0.55 * *$ & $0.48^{*}$ & $0.61 * *$ & $0.53 * *$ & $0.86 * *$ & $0.71 * *$ & $(0.88)$ & - \\
\hline Normative commitment & 4.13 & 0.59 & $0.68 * *$ & $0.60 * *$ & $0.46 *$ & $0.41^{*}$ & $0.66 * *$ & $0.51 * *$ & $0.87 * *$ & $0.71 * *$ & $0.74 * *$ & $(0.88)$ \\
\hline
\end{tabular}

$N=839$

Correlation values $r \geq 0.30 \leq 0.49$ are practically significant (medium effect). Correlation values $r \geq 0.50$ are practically significant (large effect).

$*, p \leq 0.01 ; * *, p \leq 0.001$. 
TABLE 2: Standard regression analysis: Job satisfaction as a predictor of organisational commitment.

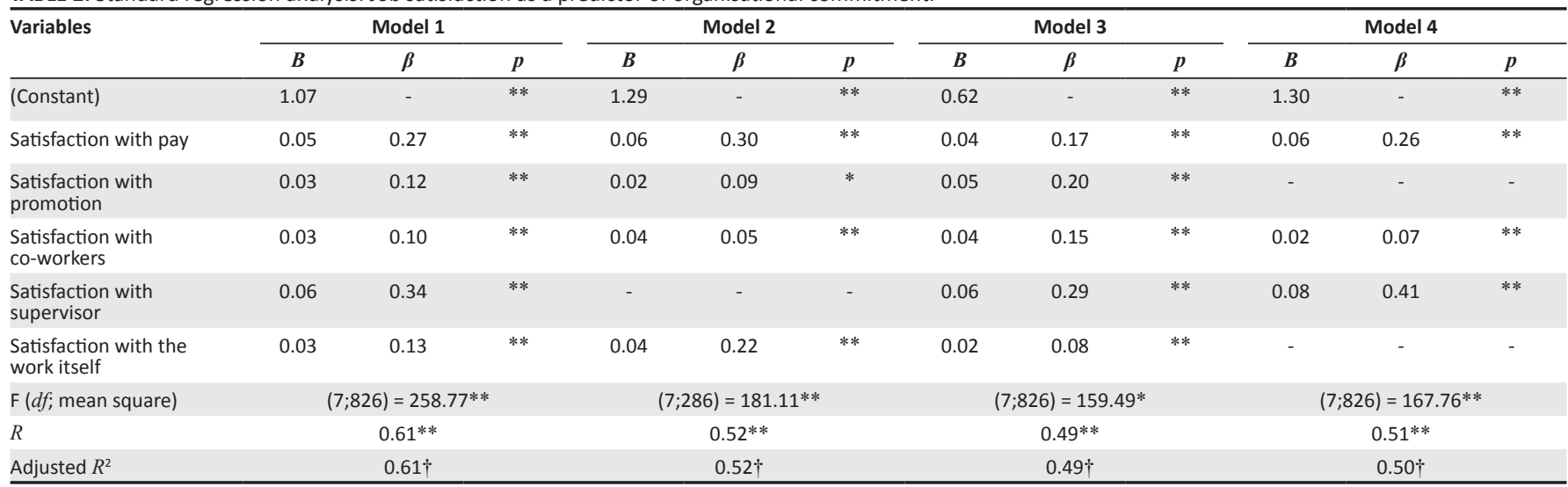

$N=839 ; B$, unstandardised regression coefficient; $\beta$, standardised regression coefficient; $d f$, degrees of freedom.

$*, p \leq 0.01 ; * *, p \leq 0.001 ; \uparrow, R^{2} \geq 0.26$ (large practical effect).

supervisor and satisfaction with the work itself produced a statistically significant regression model $\left(F_{(7,826)}=159.49\right)$, accounting for $49 \%\left(R^{2}=0.49 ; p \leq 0.001\right.$; large practical effect $)$ of variance in normative commitment. More specifically, satisfaction with supervisor $(\beta=0.29 ; t=8.26$; $p \leq 0.001)$, satisfaction with promotion $(\beta=0.20 ; t=5.97 ; p \leq 0.001)$, satisfaction with pay $(\beta=0.17 ; t=4.97 ; p \leq 0.001)$, satisfaction with co-workers $(\beta=0.15 ; t=4.89 ; p \leq 0.001)$ and satisfaction with the work itself $(\beta=0.08 ; t=2.15 ; p \leq 0.001)$ contributed significantly towards explaining the proportion of variance in the normative commitment OCS variable.

The JS variables of satisfaction with pay, satisfaction with co-workers and satisfaction with supervisor produced a statistically significant regression model $\left(F_{(7,826)}=167.76\right)$, accounting for $51 \%\left(R^{2}=0.50 ; p \leq 0.001\right.$; large practical effect $)$ of variance in overall commitment. More specifically, satisfaction with supervisor $(\beta=0.41 ; t=11.66$; $p \leq 0.001)$, satisfaction with pay $(\beta=0.26 ; t=8.06 ; p \leq 0.001)$ and satisfaction with co-workers $(\beta=0.07 ; t=2.27 ; p \leq 0.001)$ contributed significantly towards explaining the proportion of variance in the total commitment variable.

\section{Discussion}

The aim of this study was to measure the nature of the relationship between employees' levels of JS and OC in a public railway organisation in the DRC. Statistically, the aim was firstly to determine whether JS is significantly related to OC and secondly to determine whether JS serves as a predictor of OC in this organisation.

The results of the profile of the sample showed that employees experience a high level of JS. This implies that they feel satisfied with their working conditions, the opportunity for personal growth, reward system and relationship with colleagues. These findings are similar to those of previous studies by Yeh (2014), who found that employees who work in a positive environment, with proper facilities and adequate extrinsic and intrinsic reward systems, tend to be satisfied. Further, the results suggest that employees possess a high level of commitment. This could be explained by the fact that employees believe it is morally right to continue to stay for a long term with the organisation, because of the cost of leaving. These findings correspond to those of a previous study by Budiman, Anantadjaya and Prasetyawati (2014).

Overall, the results showed that JS did influence the employees' level of OC towards the organisation. Specifically, satisfaction with supervisor, satisfaction with pay, satisfaction with the work itself, satisfaction with promotion and satisfaction with co-workers significantly and positively influenced affective commitment. Satisfaction with pay, satisfaction with the work itself, satisfaction with promotion and satisfaction with supervisor positively influenced the participants' continuance commitment. The results also indicated that satisfaction with supervisor, satisfaction with promotion, satisfaction with pay, satisfaction with co-workers and satisfaction with the work itself positively influenced the employees' normative commitment to the organisation. The results further indicated that satisfaction with supervisor, satisfaction with pay and satisfaction with co-workers positively influenced the participants' overall commitment to the organisation.

The research showed that JS is related to employees' affective, normative and continuance commitment and overall level of commitment to the organisation. A high level of satisfaction with pay, promotion and co-workers related to a high level of employee commitment. Hence when individuals have a positive experience of rewards and compensation, fair promotion practices and positive relationships with colleagues, they are more likely to be psychologically attached to the organisation. This finding supports the results of Aziri (2008:80). High levels of compensation, fairness and positive relationships relate positively to high levels of employee loyalty to the organisation. Employees who have positive relationships with colleagues and congruency between their compensation and invested effort are likely to be committed to the organisation. Furthermore, the level of satisfaction with supervisor and the work itself related to a high level of employee commitment. This indicates that when employees perceive their supervisor to be competent, fair and trusting and providing positive working conditions, 
they are likely to embrace and align with the set goals and values, to make an effort and to show devotion and loyalty to the organisation. These results concur with the research findings of Unal (2012:100) and Weihui and Deshpande (2014:3). It is thus evident that employees' perception of their JS has a strong association with level of commitment.

OC reflects an individual's loyalty to, identification with and participation in the organisation. This psychological attitude and behaviour also reflect a desire that develops when employees see their individual employment to be congruent with the goals and values of the organisation for which they are currently working (Meyer \& Herscovitch 2001:301; Weihui \& Deshpande 2014:4)

The regression analyses revealed the following: it was found that affective commitment was significantly predicted by JS (satisfaction with supervisor, satisfaction with the work itself, satisfaction with pay, satisfaction with promotion and satisfaction with co-workers). Hence when employees perceive their supervisor to be competent and honest, providing fair compensation, working conditions, advancement and positive relationships with colleagues, they will be emotionally bound to the organisation (see Fu et al. 2011:540). In addition, it was found that continuance commitment was predicted by satisfaction with pay, satisfaction with the work itself, satisfaction with promotion and satisfaction with supervisor. This implies that when employees have positive perceptions about and experiences of the reward system, working conditions, promotion practices and are allowed to participate in the decision-making, they will experience OC. These results endorse the findings of previous research (Qureshi et al. 2011:660). Furthermore, it was found that normative commitment was predicted by satisfaction with supervisor, satisfaction with promotion, satisfaction with pay, satisfaction with co-workers and satisfaction with the work itself. Employees who perceive their supervisor to be honest, to value and reward their work, to show concern for their growth, to reward or compensate them fairly, to facilitate a supportive work environment and provide incentives will feel indebted to and remain in the organisation (Malik et al. 2010:18-19). These findings are consistent with those of previous research by Fu and Deshpande (2013:8), who reported that employees' JS significantly predicted affective, continuance and normative commitment.

\section{Implications for management practices}

The research showed a strong positive relationship between JS and employees' OC. The results should add value to the OC literature by shedding light on how employees' positive perceptions of their JS in a DRC railway employment setting relate to their levels of OC. The results also lend support to the findings of Unal (2012:100) and Namasivayam and Zhao (2007:1213), who reported that the relationship between JS and employees' OC tended to be positively and significantly related. Employees' affective commitment (indicative of their high JS) was found to be an important determinant of their OC. In practical terms, this result emanated from the observed association between perceived JS and the employees' affective, continuance, normative and overall organisational commitment. This data could be used to retain employees and improve their performance in the DRC transport and railway sector.

The results should also have interesting implications for top management and human resource practitioners. They could use this information to study how organisational psychological attachment is fostered in order to potentially master other organisational dynamics. The information could also be used to create positive working conditions with a view to reinforcing OC. JS manifested as a critical driver of OC, which could result in superior business performance. Management could use the results to create a working environment that actively fosters satisfaction and boosts employees' level of commitment.

\section{Limitations and recommendation for future research}

This study had a number of limitations. Firstly, the research was conducted in a single organisation. Although this approach facilitates a deeper understanding of the constructs and the dynamics under investigation, it would not be possible to generalise the findings to other regions or industries. Hence future studies could investigate the same relationships across different sectors, organisations and industries. Secondly, a cross-sectional design was used, which typically provides only a snapshot of the interplay of the JS and OC variables at a given time. This therefore limited the ability of the researchers to explore how the constructs under investigation might have shifted over time. This matter could be addressed by using a longitudinal design in future research. In addition, a voluntary survey of this kind could pose a limitation in the sense that the perceptions and reasons for non-participation are unclear. Finally, the use of only two variables does not adequately reflect the complexity of internal and external variables at play in the day-to-day unfolding of organisational life. It is suggested that the relationship between and impact of other variables should be explored, such as organisational structure, size and leadership, as proposed by Sempane, Rieger and Roodt (2002:25), as well as culture, climate, organisational citizenship behaviour and work engagement.

\section{Conclusions}

The results of this research revealed that employees' JS variables of satisfaction with supervisor, satisfaction with pay, satisfaction with the work itself, satisfaction with promotion and satisfaction with co-workers influenced their level of affective, continuance, normative and overall commitment in the railway organisation in the DRC, which could positively influence employees' intention to stay with the organisation. This implies that should employees' JS be developed or 
enhanced, their psychological and emotional attachment and loyalty to the organisation would be improved. This research thus builds on the current debate on the relationship between JS and OC. Developing employees' level of positive affective orientation towards their employment might enhance not only their affective response, involvement with organisational goals and values, loyalty and attachment but also their intention to stay in the organisation and their level of performance, while reducing absenteeism.

\section{Acknowledgements Competing interests}

We do hereby declare that there is no conflict of interest and that this article was only submitted to Acta Commercii for review and publication.

\section{Authors' contributions}

J.M.M. was the project leader and was responsible for the conceptualisation and research methodology. A.P.F. conducted the literature review and contributed to the write-up of the manuscript. F.C. assisted with the direction (conceptualisation) of the project, the write-up and editing of the manuscript.

\section{References}

Aamodt, M.G., 2007, Industrial and organisational psychology: An applied approach Thomson Higher Education, Belmont, CA.

Allen, N. \& Meyer, J., 1990, 'The measurement and antecedents of affective, continuance and normative commitment to the organisation', Journal of Occupational Psychology 63, 1-18. https://doi.org/10.1111/j.2044-8325.1990.tb00506.x

Armstrong, M., 2006, 'Human resource management: A case of the emperor's new clothes', Personnel Management 4, 30-35.

Asiedu, M., Sarfo, J.O. \& Adjei, D., 2014, 'Organisational commitment and citizenship behaviour: Tools to improve employee performance an internal marketing approach', European Scientific Journal 10(4), 288-305.

Ayeni, C.O. \& Phopoola, S.O., 2007, 'Work motivation, job satisfaction and organisational commitment of library personnel in academic and research libraries in Oyo State, Nigeria', Library Philosophy and Practice 11(1), 150-159.

Aziri, B., 2008, 'Job satisfaction: A literature review', Management Research and Practice 3(4), 77-86.

Beer, M., 2009, High commitment, high performance, Wiley, London.

Brown, S.P. \& Peterson, R.A., 1993, 'Antecedents and consequences of salesperson job satisfaction: Meta-analysis and assessment of causal effects', Journal of Marketing Research 30(1), 63-77. https://doi.org/10.2307/3172514

Budiman, A., Anantadjaya, S.P. \& Prasetyawati, D., 2014, 'Does job satisfaction influence organizational citizenship behavior? An empirical study in selected 4-sta hotels in Jakarta, Indonesia', An Empirical Study in Selected 3(1), 130-149.

Carmeli, A. \& Freund, A., 2004, 'Work commitment, job satisfaction, and job performance: An empirical investigation', International Journal of Organisation Theory and Behavior 7(3), 289-309. https://doi.org/10.1108/IJOTB-07-03-2004-B001

Chiu, W.Y.B. \& Ng, F.F., 2013, 'Improvement of job satisfaction and organisational commitment through work group identification: An examination of the quantity surveyors in Hong Kong', Australasian Journal of Construction Economics and Building 13(3), 80-95. https://doi.org/10.5130/ajceb.v13i3.3316

Coetzee, M. \& Schreuder, A.M.G., 2015, 'Career anchors, organisational commitment and employee turnover intention in the retail sector', South African Journal of Labour Relations 39(2), 105-122.

Cohen, J., 1992, 'Quantitative methods in psychology: A power primer', Psychological Bulletin 112(1), 155-159. https://doi.org/10.1037/0033-2909.112.1.155

Cohen, J., 2007, Multiple commitments in the workplace: An integrative approach, Lawrence Erlbaum Associates, London.

Cohen, L., Manion, L. \& Morrison, K., 2013, Research methods in education, 6th edn., Routledge, Abingdon, Oxford.

Curry, J., Wakefield, D., Price, J. \& Mueller, C., 1986, 'On the causal ordering of job satisfaction and organizational commitment', Academy of Management Journal 29, 847-858. https://doi.org/10.2307/255951

Ebert, R.J. \& Griffin, R.W., 2009, Business essentials, 7th edn., Pearson Education, Austin, TX.
Evans, P., Pucik, V. \& Bjorkman, I., 2011, The global challenge: International human resources management, 2 nd edn., McGraw-Hill, Singapore.

Faragher, E.B., Cass, M. \& Cooper, C.L., 2005, 'The relationship between job satisfaction and health: A meta-analysis', Occupational and Environmental Medicine 62, 105-112. https://doi.org/10.1136/oem.2002.006734

Fu, W. \& Deshpande, S.P., 2013, 'The impact of caring climate, job satisfaction and organizational commitment on job performance of employees in a Chinese insurance company', Journal of Business Ethics 124(2), 1-11.

Fu, W., Deshpande, S.P. \& Zhao, X., 2011, 'A multidimensional analysis of ethical climate, job satisfaction, organizational commitment, and organizational citizenship behaviours', Journal of Business Ethics 104(4), 537-543. https://doi.org/10.1007/ s10551-011-0928-4

Huang, C.C., You, C.S. \& Tsai, M.T., 2012, 'A multidimensional analysis of ethical climate, job satisfaction, organizational commitment, and organizational citizenship behaviours', Nursing Ethics 19(4), 513-529. https://doi.org/10.1177/ 0969733011433923

Humphreys, J., Weyant, L. \& Sprague, R.D., 2003, 'Predicting organizational commitment: The roles of emotional and practical intellect within the leader/ follower dyad', Journal of Business and Management 9(2), 189-209.

Hunt, S.D., Chonko, L.B. \& Wood, V.R., 1985, 'Organisational commitment and marketing', Journal of Marketing 49, 112-126. https://doi.org/10.2307/1251181

Judeh, M., 2011, 'Role ambiguity and role conflict as mediators of the relationship between socialisation and organisational commitment', International Business Research 4(3), 171-181. https://doi.org/10.5539/ibr.v4n3p171

Kanyurhi, E.B., 2016, 'International marketing, employee job satisfaction and perceived organisational performance in micro-finance institutions: Empirical study from Kivu Province (DRC)', International Journal of Bank Marketing 34(5), 1-42. https://doi.org/10.1108/IJBM-06-2015-0083

Kotze, K. \& Roodt, G., 2005, 'Factors that affect the retention of managerial and specialist staff: An exploratory study of an employee commitment model', South African Journal of Human Resource Management 3(2), 48-55. https://doi.org/ 10.4102/sajhrm.v3i2.65

Lee, E.J. \& Cha, P., 2015, 'Effects of work environment and resilience on job satisfaction and organisational commitment of social workers in juvenile reformatory schools', Indian Journal of Science and Technology 8(1), 360-366. https://doi.org/10.17485/ ijst/2015/v8iS1/59331

Locke, M., 1976, 'Organizational behaviour: Affect in the workplace', Annual Review of Psychology 53, 279-307.

Lok, P. \& Crawford, J., 2004, 'The effect of organizational culture and leadership style on job satisfaction and organizational commitment: A cross-national comparison' Journal of Management Development 23(4), 321-338. https://doi.org/10.1108/ 02621710410529785

Lumley, E.J., Coetzee, M., Tladinyane, R.T. \& Ferreira, N., 2011, 'Exploring the job satisfaction and organisational commitment of employees in the information technology environment', Southern African Business Review 15(1), 100-118.

Malik, M.E., Nawab, S., Naeem, B. \& Danish, R.Q., 2010, 'Job satisfaction and organisational commitment of university teachers in public sector in Pakistan' International Journal of Business Management 5(6), 17-26. https://doi.org/ 10.5539/ijbm.v5n6p17

Mamman, A., Kamoche, K. \& Bakuwa, R., 2012, 'Diversity, organizational commitment and organizational citizenship behavior: An organizing framework', Human Resource Management Review 22(4), 285-302. https://doi.org/10.1016/j.hrmr. 2011.12.003

Mathieu, J. \& Zajac, D., 1990, 'A review and meta-analysis of the antecedents, correlates and consequences of organisational commitment', Psychological Bulletin 108(2), 171-194. https://doi.org/10.1037/0033-2909.108.2.171

Meyer, J.P. \& Allen, N.J., 1991, 'A three-component conceptualization of organisational commitment', Human Resource Management Review 1(1), 61-89. https://doi. org/10.1016/1053-4822(91)90011-Z

Meyer, J.P. \& Allen, N.J., 1997, Commitment in the workplace: Theory, research and application, Sage, London.

Meyer, J.P. \& Herscovitch, L., 2001, 'Commitment in the workplace: Towards a general model', Human Resource Management Review 11, 299-326. https://doi.org/ 10.1016/S1053-4822(00)00053-X

Meyer, J.P., Stanley, D.J., Herscovitch, L. \& Topolnytsky, L., 2002, ‘Affective, continuance, and normative commitment to the organization: A meta-analysis of antecedents, correlates, and consequences', Journal of Vocational Behavior 61(1), 20-52. https://doi.org/10.1006/jvbe.2001.1842

Mminele, M., 2014, DTI: Statement by Lubumbashi-based Consul-General of South Africa in the Katanga Province of DRC, on DRC opportunities will not last forever, viewed 03 June 2016, from Polity.org.za.

Mokime, M. \& Bamou, B., 2015, African Economic Outlook: Regional development and spatial inclusion, OECD Publishing, Abidjan.

Mueller, C.W., Boyer, E.M., Price, J.L. \& Iverson, R.D., 1994, 'Employee attachment and non-coercive conditions of work: The case of dental hygienists', Work and Occupations 21, 179-212. https://doi.org/10.1177/07308884940210 02002

Namasivayam, K. \& Zhao, X., 2007, 'An investigation of the moderating effects of organizational commitment on the relationship between work-family conflict and job satisfaction among hospitality employees in India', Tourism Management 28 1212-1223. https://doi.org/10.1016/j.tourman.2006.09.021

Narteh, B., 2012, 'Relationship marketing and customer loyalty: Evidence from the Ghanian Luxury Hotel Industry', Journal of Hospitality Marketing \& Management 22(4), 407-436. https://doi.org/10.1080/19368623.2012.660564 
Ng, E.S.W. \& Wyrick, C., 2011, 'Motivational bases for managing diversity: A model of leadership commitment', Human Resource Management Review 21(4), 368-376. https://doi.org/10.1016/j.hrmr.2011.05.002

Nunnally, C.J. \& Bernstein, I.H. 2010, Psychometric theory, McGraw-Hill, New York.

Obi-Nwosu, H., Chiamaka, J. \& Tochukwu, O., 2013, 'Job characteristics as predictors of organisational commitment among private sector workers in Anambra State, Nigeria', International Journal of Asian Social Science 3(2), 482-491.

Özturk, F., 2010, 'Determinants or organisational citizenship behaviour among knowledge workers: The role of job characteristics, job satisfaction, and organisational commitment', Unpublished master's dissertation, Middle East Technical University, Ankara, Turkey.

Qureshi, J., Hayat, N.K., Ali, M. \& Sarwat, N.K., 2011, 'Impact of strategic leadership on organizational performance, in the context of job satisfaction and organizational commitment: Evidence from educational institutions of Pakistan', Interdisciplinary Journal of Contemporary Research in Business 3(4), 658-675.

Rashid, M.Z.A., Sambasivan, M. \& Johari, J., 2003, 'The influence of corporate culture and organisational commitment on performance', Journal of Management Development 22(8), 708-728. https://doi.org/10.1108/02621710310487873

Reichers, A.E., 1985, 'A review and reconceptualization of organizational commitment', Academy of Management Review 10, 465-476.

Robbins, P.S., 1993, Organizational behaviour: Concepts, controversies and applications, Prentice-Hall, Jersey City, NJ.

Robertson, I. \& Cooper, C.L., 2011, Wellbeing: Productivity and happiness at work, Palgrave Macmillan, London.

Rutherford, B., Boles, J.G., Hamwi, A., Madupalli, R. \& Rutherford, L., 2009, 'The role of the seven dimensions of job satisfaction in salespersons' attitudes and behaviors', Journal of Business Research 62(11), 1146-1151. https://doi.org/ 10.1016/j.jbusres.2008.10.019

Salkind, J.N., 2014, Exploring research, 7th edn., Prentice Hall, Upper Saddle River, NJ.

Schmidt, S.W., 2007, 'The relationship between satisfaction with workplace training and overall job satisfaction', Human Resource Development Quarterly 18, 481-498. https://doi.org/10.1002/hrdq.1216

Sehunoe, N., Viviers, R. \& Mayer, C-H., 2015, 'Job satisfaction, organizationa commitment and work engagement in an insurance company', South African Journal of Labour Relations 39(2), 123-144.

Sempane, M.E., Rieger, H.S. \& Roodt, G., 2002, 'Job satisfaction in relation to organizational culture', South African Journal of Industrial Psychology 28(2), 23-30. https://doi.org/10.4102/sajip.v28i2.49

Shaugnessy, J.J. \& Zechmeister, E.B., 2003, Research methods in psychology, 6th edn., McGraw-Hill, New York.
Smith, P.C., Kendall, L.M. \& Hulin, C.L., 1969, The measurement of satisfaction in work and retirement, Rand McNally, Chicago, IL.

Spagnoli, P. \& Caetano, A., 2012, 'Personality and organisational commitment: The mediating role of job satisfaction during socialisation', Career Development International 17(3), 255-275. https://doi.org/10.1108/13620431211241081

SPSS, 2017, SPSS for Windows, SPSS Inc., Chicago, IL.

Stander, M.W. \& Rothmann, S., 2010, 'Psychological empowerment, job insecurity, and employee engagement', South African Journal of Industrial Psychology 36(1), 1-8. https://doi.org/10.4102/sajip.v36i1.849

Swaminathan, S. \& Jawaher, P., 2013, 'Job satisfaction as a predictor of organizational citizenship behavior', Global Journal of Business Research 7(1), 71-80.

Tabachnick, B.G. \& Fidell, L.S., 2010, Using multivariate statistics, 5th edn., Allyn \& Bacon, Boston, MA.

Tredoux, C. \& Durrheim, K., 2013, Numbers, hypotheses, and conclusions, 2nd edn. UCT Press, Cape Town

Unal, O.F., 2012, 'Relationship between organizational commitment and ethical climate: The mediating role of job satisfaction dimensions', Journal of WEI Business and Economics 1(1), 92-105.

Viljoen, J.P. \& Rothmann, S., 2009, 'Occupational stress, ill health and organisational commitment of employees at a university of technology', South African Journal of Industrial Psychology 35, 1-11. https://doi.org/10.4102/sajip.v35i1.730

Vitell, S.J. \& Davis, D.L., 1990, 'The relationship between ethics and job satisfaction: An empirical investigation', Journal of Business Ethics 9, 489-494. https://doi. org/10.1007/BF00382842

Weihui, F. \& Deshpande, S.P., 2014, 'The impact of caring climate, job satisfaction, and organizational commitment on job performance of employees in a China insurance company', Journal of Business Ethics 124(2), 1-11.

Yeh, Y., 2014, 'Exploring the impacts of employee advocacy on job satisfaction and organizational commitment: Case of Taiwanese airlines', Journal of Air Transport Management 36(1), 94-100. https://doi.org/10.1016/j.jairtraman. 2014.01.002

Yiing, L.H. \& Ahmad, K.Z.B., 2009, 'The moderating effects of organizational culture on the relationships between leadership behaviour and organizational commitment and between organizational commitment and job satisfaction and performance', Leadership and Organisational Development Journal 30(1), 53-86. https://doi. org/10.1108/01437730910927106

Zhang, J. \& Zheng, W., 2009, 'How does satisfaction translate into performance? An examination of commitment and cultural values', Human Resource Development Quarterly 20, 331-351. https://doi.org/10.1002/hrdq.20022 